\title{
Integrated Usage of Farm Yard Manure and Urea Improves Wheat Yield and Soil Properties
}

\author{
Shahbaz Khan*1, Syed Adnan Mazhar ${ }^{2}$, Soahil Irshad ${ }^{3}$, Muhammad Nawaz ${ }^{4}$, \\ Saqib Bashir ${ }^{5}$, Muhammad Sohail Saddiq ${ }^{1}$, Ali Bushkh ${ }^{6}$ \\ ${ }^{1}$ Department of Agronomy, Ghazi University, Dera Ghazi Khan (32200), Pakistan \\ ${ }^{2}$ Institute of Soil and Environmental Sciences, University of Agriculture, Faisalabad (38040), \\ Pakistan
}

${ }^{3}$ In-Service Agricultural Training Institute, Rahim Yar Khan (64200), Pakistan.

${ }^{4}$ Department of Agricultural Engineering, Khwaja Fareed University of Engineering and Information Technology, Rahim Yar Khan (64200), Pakistan

${ }^{5}$ Department of Soil and Environmental Sciences, Ghazi University, Dera Ghazi Khan (32200), Pakistan

${ }^{6}$ Department of Plant Breeding and Genetics, Ghazi University, Dera Ghazi Khan (32200), Pakistan

*Corresponding author's email: shahbaz2255@gmail.com shkhan@gudgk.edu.pk ORCID 0000-0002-4524-9630, Researcher ID U-2918-2019

Keywords: Economical yield, fertilizer, hydraulic conductivity, particle density, plant height.

\begin{abstract}
Optimum usage of fertilizers is an important factor that defines the fate of crop yield by confirming the accessibility of nutrients in soil. Imbalance use of fertilizer not only reduces the crop productivity but also adversely affects the soil properties. A one-year experiment was carried out to explore the impact of different levels of farm yard manure and urea on soil properties, growth and yield of wheat crop. Treatments were application of nitrogen at i) $125 \mathrm{~kg} \mathrm{ha}^{-1}$ from urea, ii) $80 \mathrm{~kg} \mathrm{ha}^{-1}$ of nitrogen from urea +10 tons of farm yard manure ha-1 and iii) 20 tons of farm yard manure $\mathrm{ha}^{-1}$. Wheat cultivar Sehar-2006 was used in the experiment. All the treatments' combination affected crop growth, economic yield and soil properties. However, maximum positive impact of combined use of farm yard manure and urea was observed. Results indicated that productive tillers per unit area (16\%), plant height, number of spikelets per spike $(12.5 \%)$ and economical yield (11\%) were greatly enhanced by combined usage of urea and farm yard manure as compared to sole application of urea. Combined application of urea and farm yard manure also positively affected the soil bulk density, particle density, percent porosity and soil saturated hydraulic conductivity as compared to either sole use of urea or farm yard manure. Combined usage of farm yard manure and urea are suggested better to produce higher economical yield along with improved soil properties.
\end{abstract}

\section{Introduction}

Wheat is of prime importance as it is the staple food of masses in Pakistan. A number of farmers grow wheat on large area ( 9 million hectares) in winter season. Only wheat crop has contributed a big share of almost 10\% in value addition in the agriculture sector and 2\% in GDP of the country in 2017 [1]. It ranks second after rice in terms of dietetic consumption as main and staple food crop. Presently, around $65 \%$ of wheat is being consumed as a food purpose [2]. Nitrogen (N) is an important yieldrestrictive plant macronutrient [3]. All plants utilize $\mathrm{N}$ in the form of $\mathrm{NO}_{3}{ }^{-}$and $\mathrm{NH}_{4}{ }^{+}$. It is the most imperative element for proper growth and development of plant which significantly increases and enhances the yield and its quality by playing vital role in biochemical and physiological functions of plants [4]. Deficiency of N causes reduced growth, appearances of chlorosis (changing of the green color into yellow color of older leaves) and restrict lateral bud growth (from which leaves, stem and branches develop) [5]. Nitrogen deficiency in crop plants resulted in less light absorption by lessening leaf area index that was the major reason in reduction of grain yield [6]. Nitrate losses through 
leaching not only reduce soil fertility rather it poses serious threat to environment and humans too [7].

Various management practices, nitrogen fertilizer source, manure application and tillage operations sturdily affect the extent of leaching of nitrate in soil [8]. It is well known fact that usage of nitrogen fertilizer is a main contributor in increasing agricultural production in recent past years [9]. According to a study, nitrogenous fertilizers utilization globally is approximately more than 80 MMT annually, that is chiefly used to boost the crop growth and ultimately yield too [10]. In Pakistan, almost 92\% of the farmer community used synthetic nitrogen fertilizers and round about $78 \%$ of the total fertilizers used are $\mathrm{N}$ fertilizers [11].

Organic matter, in agriculture, is one of the most important soil quality and productivity parameters. Amount of organic matter in soil directly affects the total carbon contents along with organic carbon which is managed by the process of mineralization. It has therefore, pivotal role in erosion control, soil stability, water penetration and conversion of nutrients in soil [12]. Huge amount of organic waste is supplemented to arable land to dispose off and recycling of nutrients [9]. Organic wastes are rich source of nutrients especially $\mathrm{N}$ and can assist as valued nutrient source for agricultural production if the source is properly known. Sing and Sing [13] reported that combined application of FYM and $\mathrm{P}_{2} \mathrm{O}_{5}$ improved the grain yield of wheat crop. Zahoor et al. [14] reported that use of integrated sources of nitrogen like organic and inorganic are responsible for efficient utilization of N. This practice is also less susceptible to losses. Mazhar et al. [15] stated that combined application of FYM and urea improved the yield parameters of wheat crop by increasing the availability of nutrients to crop plants. Integrated usage of urea and FYM is either useful or not to enhance the productivity of wheat crop along with improvement of soil properties. Current study was designed with following objectives: (i) to evaluate the impact of integrated and sole application of urea and FYM on soil properties like particle density, bulk density, \% porosity, soil saturated and hydraulic conductivity, (ii) to investigate the effect of integrated and sole application of urea and FYM on the growth and yield of wheat crop.

\section{Material and Methods}

\section{Experimental Particulars}

A one-year field study was carried out to investigate the impact of various combinations of farm yard manure and urea on soil properties and wheat yield at research area of Institute of Soil and Environmental Sciences, University of Agriculture, Faisalabad-Pakistan $\left(31.25^{\circ} \mathrm{N}, 73.09^{\circ} \mathrm{E}\right)$. Before conducting experiment, samples of soil were collected for physical and chemical properties of soil (Table 1). Results indicated that soil of experimental area was calcareous in nature and was poor in NP contents. Faisalabad is semi-arid region owing to high rate of evapo-transpiration with annual rainfall of approximately $200 \mathrm{~mm}$. Wheat cultivar, Sehar-2006, was used as test crop and seed of the variety was obtained from Punjab Seed Corporation (PSC), Ayyub Agriculture Research Institute (AARI), Faisalabad-Pakistan. The trail was arranged in randomized complete block design (RCBD) with three replications having net plot size of $6.75 \mathrm{~m} \times 8.50 \mathrm{~m}$.

\section{Crop husbandry}

Seedbed was prepared by using cultivator and planker. Sowing of wheat was done in well prepared seedbed by using single row hand drill having row spacing of $22.5 \mathrm{~cm}$ and seed rate of $100 \mathrm{~kg} \mathrm{ha}^{-1}$. Treatments comprised; application of $125 \mathrm{~kg}$ of nitrogen per hectare from urea, $80 \mathrm{~kg}$ of nitrogen from urea +10 tons of FYM per hectare and 20 tons of FYM per hectare. FYM was added to plots before land preparation. Sources of NP and K were urea, di-ammonium phosphate and sulphat of potash respectively. All the dose of $\mathrm{P}$ and $\mathrm{K}$ were supplemented at sowing time while $\mathrm{N}$ was applied into three splits. Necessary crop protection measures were taken uniformly to evade the competition by weeds. Field was kept free from insects, pests and diseases. Manual harvesting of crop was done and kept in field for sun drying for seven days after that threshing was done manually.

\section{Yield Parameters}

Yield parameters like number of productive tillers were counted in unit area from each repeat at maturity and average was calculated. Regarding plant height, meter rod was used for measurement at interval of 15 days which was started from 30 days after sowing till maturity of crop. Number of 
spikelets per spike were counted manually. For the measurement of grain yield, fully mature crop was harvested manually from an area of $1 \mathrm{~m}^{2}$ and obtained grains were weighed by the use of weighing balance after threshing. Harvest index was calculated by following formula:

Harvest index $=$ Grain yield $/$ Biological yield $\times 100$

\section{Soil Parameters}

Soil parameters like particle density, soil bulk density, \% porosity and soil saturated hydraulic conductivity $\left(\mathrm{mm} \mathrm{hr}^{-1}\right)$ were estimated after harvesting. Soil samples were obtained from each experimental unit after harvesting of crop according to standard procedures. Core method was used for the determination of soil bulk density as defined by Blake and Hartge [16]. The core sampler was pressed into the soil for enough depth to fill the core. Carefully removed the sampler and trimmed the soil extended out of the core with a sharp knife. Soil was oven dried at $105^{\circ} \mathrm{C}$ to a constant weight, cooled and weighed. Soil volume was then taken equal to inner volume of the core sampler $(\pi \mathrm{r} 2 \mathrm{~h})$.

Bulk density $=$ (mass of oven dried soil) $/$ (volume of soil including pore spaces)

Soil particle density was determined by using pycnometer method. $100 \mathrm{ml}$ volumetric flask was closed with a cork (having hole in the center). In this hole a capillary tube was placed for the escape of air then a known mass of soil was placed into the pycnometer. After that, water was poured into the pycnometer up to the mark. We poured known mass of water (equal to the volume of the water). Soil partial volume was determined by subtracting the volume of the water poured from $100 \mathrm{ml}$.

Particle density $=$ (mass of oven dried soil) / (volume of the soil excluding pore spaces)

Soil porosity was calculated by using the following formula;

$$
\text { Percent porosity }=1-(\text { bulk density / particle density }) \times 100
$$

Regarding the measurement of soil saturated hydraulic conductivity, Guelph permeameter (Model $2800 \mathrm{KI})$ was used by taking three steady-state readings.

\section{Statistical Analysis}

Collected data concerning soil properties and yield were statistically analyzed by using Statistix 8.1 version and the difference between treatments' means were analyzed by applying least significant difference (LSD) test at 5\% probability level [17].

\section{Results and Discussion}

\section{Yield attributes and yield}

Plant height is considered as important factor that directly relates with productivity of crop in relation with biological and economical yield. In this study, results regarding plant height showed better performance in case of combined application of urea and FYM in comparison to sole application of FYM (Fig. 1). Maximum plant height of wheat seedlings at the age of 30 days was observed in case of combined application of urea and FYM while minimum height of seedlings was recorded due to sole application of FYM (Fig. 1a). After the interval of 15 days, combined application of FYM with urea and sole application of FYM showed the results statistically at par with each other (Fig. 1b). Finally, combined application of FYM with urea produced highest plant height as compared to sole application of urea (Fig. 1c-f) while same trend was also observed regarding plant height at maturity (Fig. 1). Possible reason for maximum height in case of combined application of FYM and urea might be availability of mineral nitrogen from urea at early stage while maximum availability of nutrients from FYM at later stages. Therefore, outstanding vegetative growth ensured the highest plant length [18]. Our results are in line to the outcomes of Singh and Agarwal [19] and Iqbal et al. [20] who stated that usage of mineral nitrogen sole or in combination with organic nitrogen boosted plant height owing to greater cell division by $\mathrm{N}$, role of nitrogen in the cell enlargement and expansion that eventually influence plant height especially at vegetative growth period.

Application of different combinations of fertilizer prominently affected various yield traits like number of spikelets per spike, number of productive tillers, harvest index and grain yield (Table 2). 
Highest number of productive tillers $\left(309 \mathrm{~m}^{-2}\right)$ was produced in case of combined application of urea and FYM while lowest number $\left(142 \mathrm{~m}^{-2}\right)$ were recorded in case of sole application of FYM at 20 tons per hectare. Our findings are also similar to Arif et al. [21] who stated that maximum number of productive tillers were produced by the combined application of organic and inorganic fertilizers. Number of spikelets per spike is vital yield contributing parameter that affects the number of grains per spike and final yield of wheat. In our study, there was alike trend of number of spikelets per spike as productive tillers. Highest number of spikelets per spike (18) was recorded where combined application of fertilizer and FYM was done while least number (14) was observed in case of sole application of FYM. Possible reason of improvement in yield traits is increase in dry biomass, growth and yield due to application of FYM that supplements nutrients to crop [22]. Our results also supported the findings of Kiani et al. [23].

All the applied treatments showed positive effect on grain yield (Table 2). Integrated usage of FYM and urea produced highest economical yield $\left(4167 \mathrm{~kg} \mathrm{ha}^{-1}\right)$ while minimum economical yield was found where sole application of FYM was done. While in case of harvest index there was no significant difference among treatments' means. Increase in grain yield by integrated application of FYM and urea was due to better uptake of $\mathrm{N}$ by crop that could be accredited to decomposition and mineralization or it might be due to better root development. Soil microbes got early dose of $\mathrm{N}$ from urea that enhance mineralization process ultimately resulted in more grain yield [24]. Our results are in line with the findings of Singh and Agarwal [19], Iqbal et al. [20], Arif et al. [21] and Khan et al. [24] who stated significant boost in number of grains per spike of wheat by the combined application of manures and inorganic fertilizers. In case of harvest index, combined application of urea and FYM showed highest value of harvest index and vice versa in case of sole application of FYM (Table 2). Our results are supported by the study of Maobe et al. [25] who had conducted experiment on maize crop by combined use of organic and inorganic fertilizers as $\mathrm{N}$ source and they summarized that there was no significant effect of treatments on harvest index of maize. Findings of present experimentation are also supported by Mazhar et al. [15]. They stated that combined application of FYM and urea improved the yield parameters of wheat crop by increasing the availability of nutrients to crop plants. Sing and Sing [13] reported that combined application of FYM and $\mathrm{P}_{2} \mathrm{O}_{5}$ improved the grain yield of wheat crop. Zahoor et al. [14] reported that use of integrated sources of nitrogen like organic and inorganic are responsible for efficient utilization of $\mathrm{N}$. This practice is also less susceptible to losses. Combined usage of urea and farm yard manure $\left(80 \mathrm{~kg} \mathrm{ha}^{-1}\right.$ of $\mathrm{N}$ from urea +10 tons of farm yard manure $\mathrm{ha}^{-1}$ ) are responsible for improvement of yield and yield contributing elements.

\section{Soil Parameters}

Application of urea and FYM significantly affected soil properties. Effect of different combination of treatments on particle and bulk density of soil has shown in Fig. 2. Data show that after the harvest of crop, least particle and bulk density was recorded in case of combined application of FYM and urea while maximum particle and bulk density were observed where sole application of urea was done. While in case of sole application of FYM, there was reduction of $2.2 \%$. This might be possible owing to the effect of buildup of FYM and root density because root action can boost porosity and decrease bulk density.

This might be due to the effect of manure accumulation and root density because root activity can increase porosity and decrease bulk [22]. Results of our findings are similar to Sommerfeldt and Chang [26] who reported that organic matter in manure can cause decrease in bulk density of soil. Similar results were also reported by Mosadeghi et al. [27] who stated the reduction in bulk density of soil by the application of manure. Haynes and Naidu [28] resolute decrease in particle density of soil in case of manure application. They defined that use of manure into the soil boosted microbes by the increase in organic matter resultantly, increase in cohesion and soil stability.

Conversely, parameters like saturated hydraulic conductivity and percent porosity were observed maximum in case of sole application of FYM which was statistically at par with combined application of FYM and urea (Fig. 3). Minimum values of hydraulic conductivity and percent porosity were recorded where sole application of urea was done. This might be due to the effect of manure accumulation and root density because root activity can increase porosity and decrease bulk [22]. Our 
results are also in line with the findings of Edmeades [29]. He concluded that use of manure into soil enhanced percent porosity by enhancing micro pore spaces because of high rate of cohesion and stabilization of particles of soil. Manure application boosted field saturated hydraulic conductivity up to 76-128 [30]. Use of dairy manure enhanced field saturated hydraulic conductivity [31]. Shirani et al. [22] had same findings as for improved hydraulic conductivity in case of manure application. Iqbal et al. [31] also described that the residual dairy manure increased field saturated hydraulic conductivity. Yield of wheat is also linked with different properties of soil [32]. Integrated application of urea and farm yard manure $\left(80 \mathrm{~kg} \mathrm{ha}^{-1}\right.$ of $\mathrm{N}$ from urea +10 tons of farm yard manure $\left.\mathrm{ha}^{-1}\right)$ significantly improved the soil properties.

\section{Conclusion}

Fertilizer application is a key factor which determines the fate of the productivity of crop through confirming the nutrient availability. Combined usage of urea and FYM enhanced the productive tillers per unit area (16\%), plant height, number of spikelets per spike (12.5\%) and economical yield (11\%). Combined usage of FYM and urea are suggested better to produce higher economical yield along with improved soil properties.

\section{Conflict of Interest}

The authors declare that there is no conflict of interest.

Table 1. Physico-chemical properties of experimental soil

\begin{tabular}{cc}
\hline Determination & Values \\
\hline Chemical analysis & 7.79 \\
$\mathrm{pH}$ & 1.68 \\
$\left.\mathrm{EC}(\mathrm{dS} \mathrm{m})^{-1}\right)$ & 1.41 \\
Soil bulk density $\left(\mathrm{Mg} \mathrm{m}^{-3}\right)$ & 44.92 \\
Total Porosity $(\%)$ & 24.76 \\
Soil Infiltration Rate $\left(\mathrm{mm} \mathrm{hr}^{-1}\right)$ & 52.63 \\
Soil Hydraulic Conductivity $\left(\mathrm{mm} \mathrm{hr}^{-1}\right)$ & 0.51 \\
Total Nitrogen $\left(\mathrm{mg} \mathrm{kg}^{-1}\right)$ & 9.28 \\
Available phosphorus $\left(\mathrm{mg} \mathrm{kg}^{-1}\right)$ & 112.18 \\
Available Potassium $\left(\mathrm{mg} \mathrm{kg}^{-1}\right)$ & 2.48 \\
Soil Organic Carbon $\left(\mathrm{g} \mathrm{kg}^{-1}\right)$ & \\
Physical analysis & 47 \\
Sand (\%) & 28 \\
Silt (\%) & 24 \\
Clay $(\%)$ & Sandy clay loam \\
\hline
\end{tabular}

Table 2. Effect of fertilizer practices on yield parameters of wheat (three replicates)

\begin{tabular}{lcccc}
\hline Treatment & $\begin{array}{c}\text { Productive } \\
\text { tillers }\left(\mathrm{m}^{-2}\right)\end{array}$ & $\begin{array}{c}\text { Number of spikelets } \\
\text { per spike }\end{array}$ & $\begin{array}{c}\text { Grain yield } \\
\left(\mathrm{kg} \mathrm{ha}^{-1}\right)\end{array}$ & $\begin{array}{c}\text { Harvest index } \\
(\%)\end{array}$ \\
\hline $\mathrm{T}_{1}$; Urea & $266 \pm 14.76 \mathrm{~B}$ & $16 \pm 1.74 \mathrm{~B}$ & $3733 \pm 218 \mathrm{~B}$ & $33.93 \pm 2.03 \mathrm{~A}$ \\
$\mathrm{~T}_{2}$; Urea $+\mathrm{FYM}^{*}$ & $309 \pm 25.57 \mathrm{~A}$ & $18 \pm 0.25 \mathrm{~A}$ & $4167 \pm 201 \mathrm{~A}$ & $34.12 \pm 3.36 \mathrm{~A}$ \\
$\mathrm{~T}_{3}$; FYM & $142 \pm 15.87 \mathrm{C}$ & $14 \pm 1.01 \mathrm{C}$ & $1900 \pm 153 \mathrm{C}$ & $33.07 \pm 2.88 \mathrm{~A}$ \\
$\mathrm{LSD}(0.05)$ & 44.842 & 1.286 & 103.541 & 1.294 \\
\hline
\end{tabular}

$*$ FYM $=$ Farm yard manure, Means sharing the same letter did not differ significantly at $P=0.05$

$T_{1}=$ Urea; Recommended $N$ from Urea, $T_{2}=$ Urea $(80 \mathrm{~kg})+$ FYM $(10$ ton $)$ and $T_{3}=$ FYM $(20$ ton $)$ 
Fig. 1a. At the age of 30 days

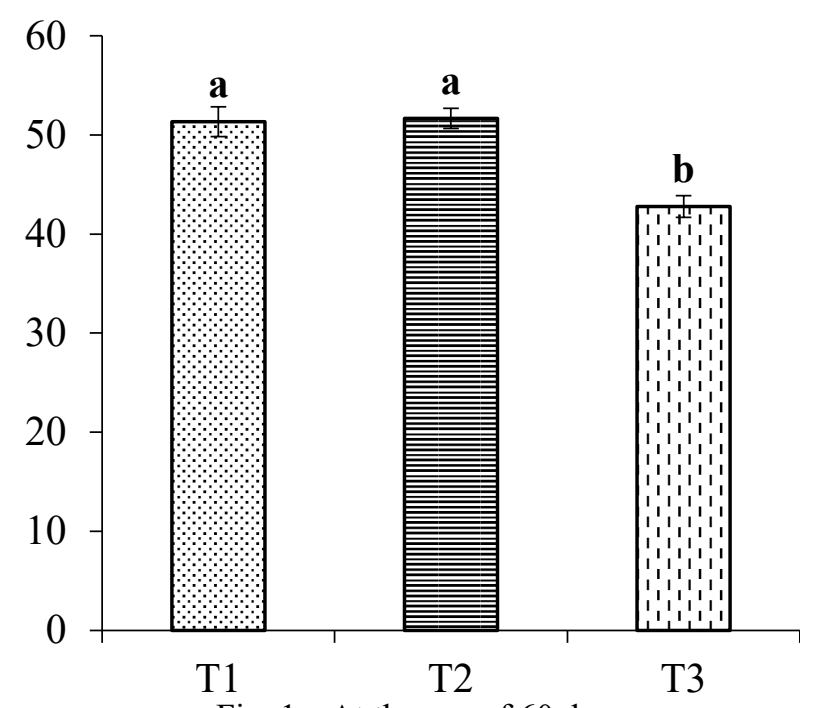

Fig. 1c. At the age of 60 days

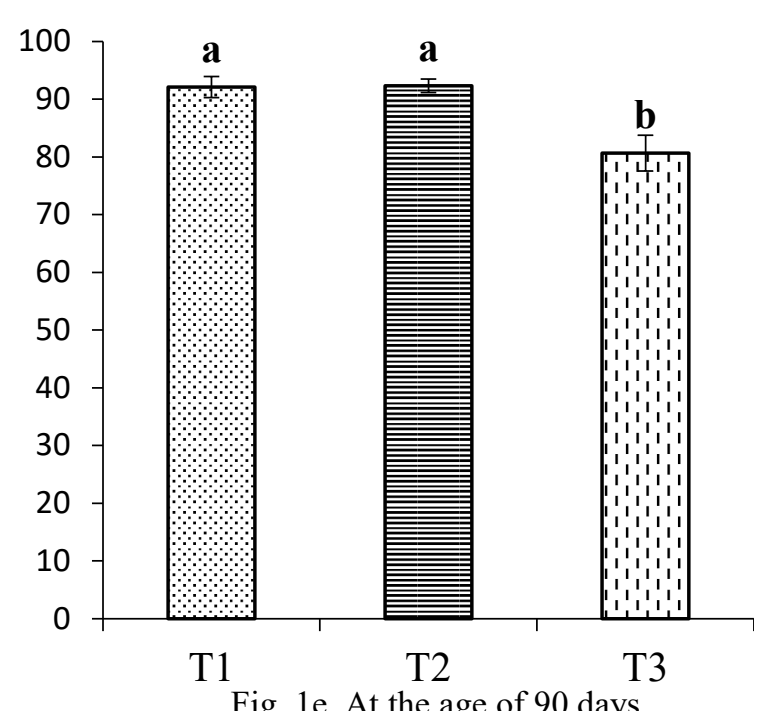

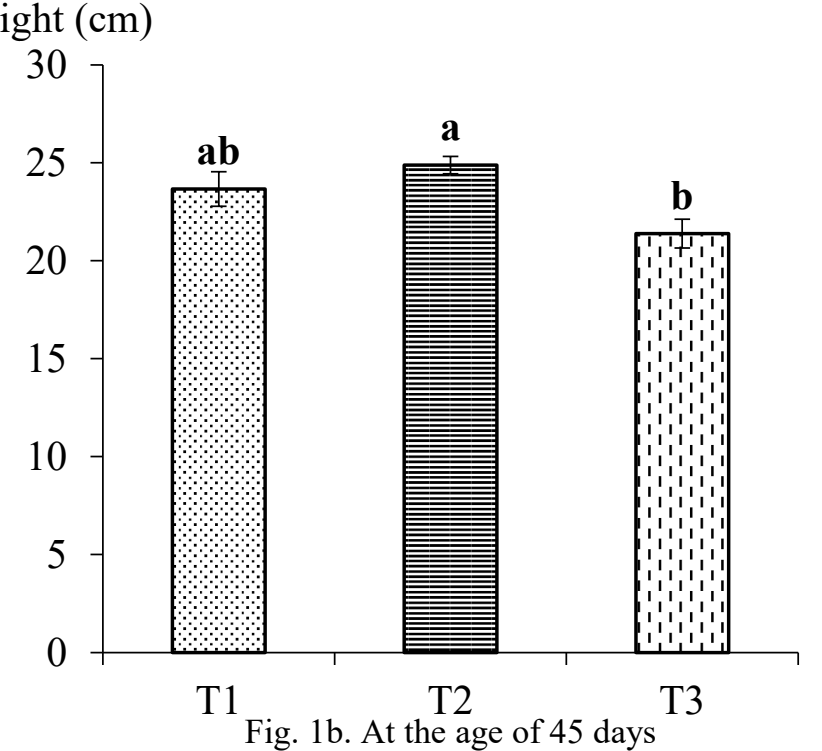

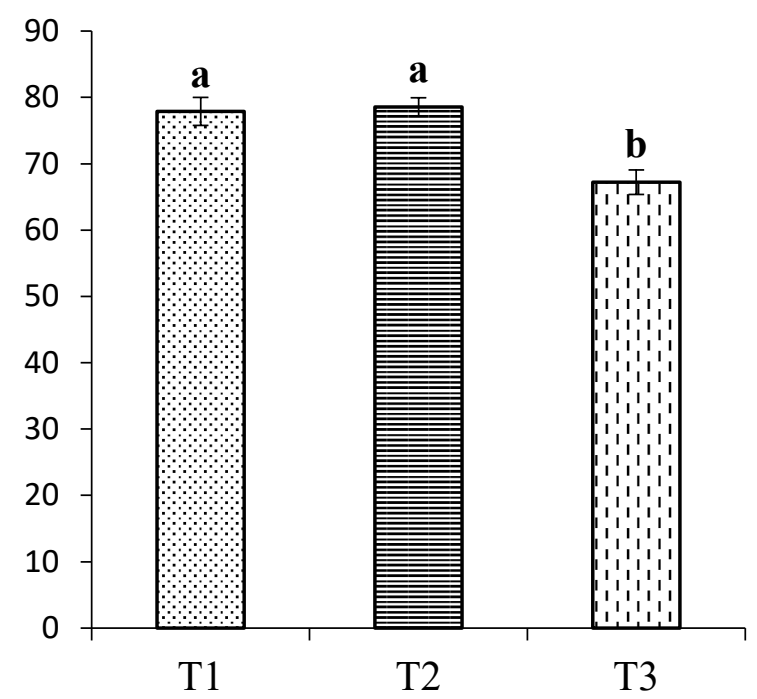

Fig. 1d. At the age of 75 days

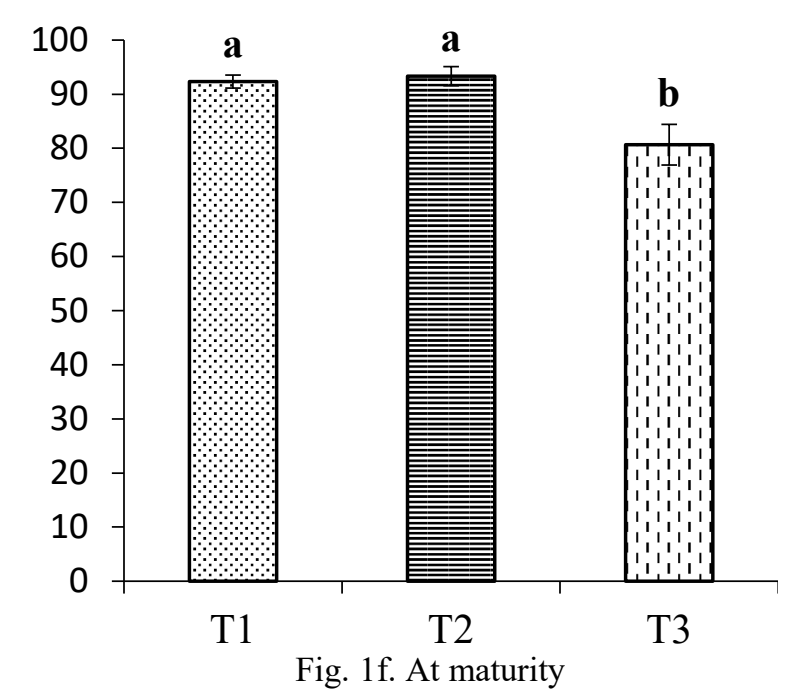

Figure 1. Effect of different fertilization strategies on plant height after an interval of 15 days (three replicates) 
Bulk Density $\left(\mathrm{mg} \mathrm{cm}^{-3}\right)$

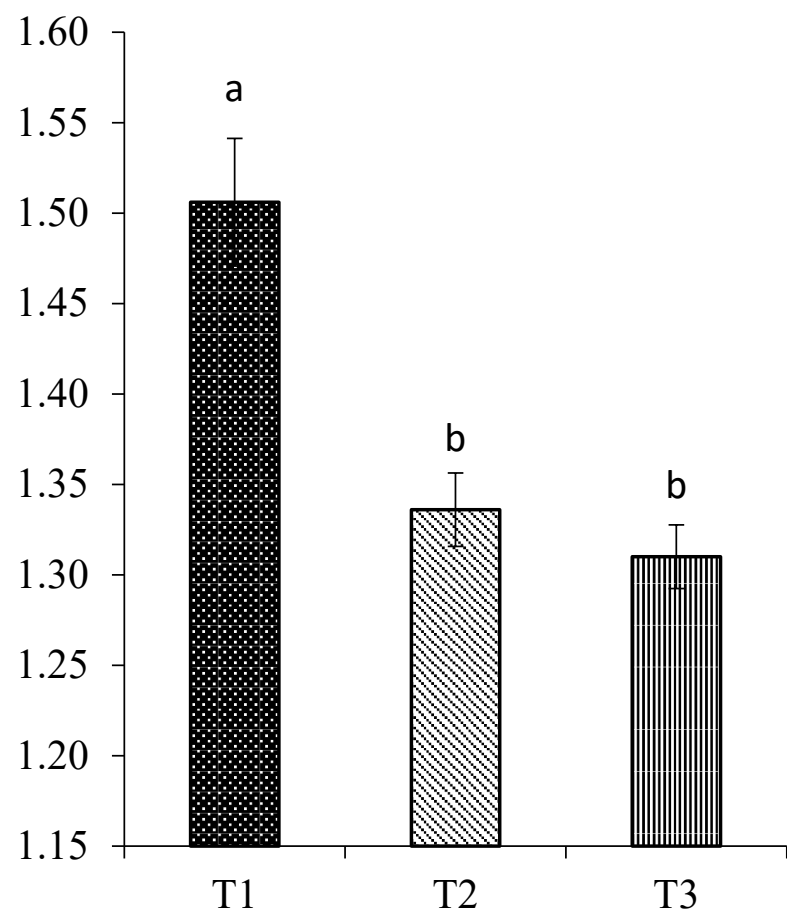

Particle Density $\left(\mathrm{mg} \mathrm{cm}^{-3}\right)$

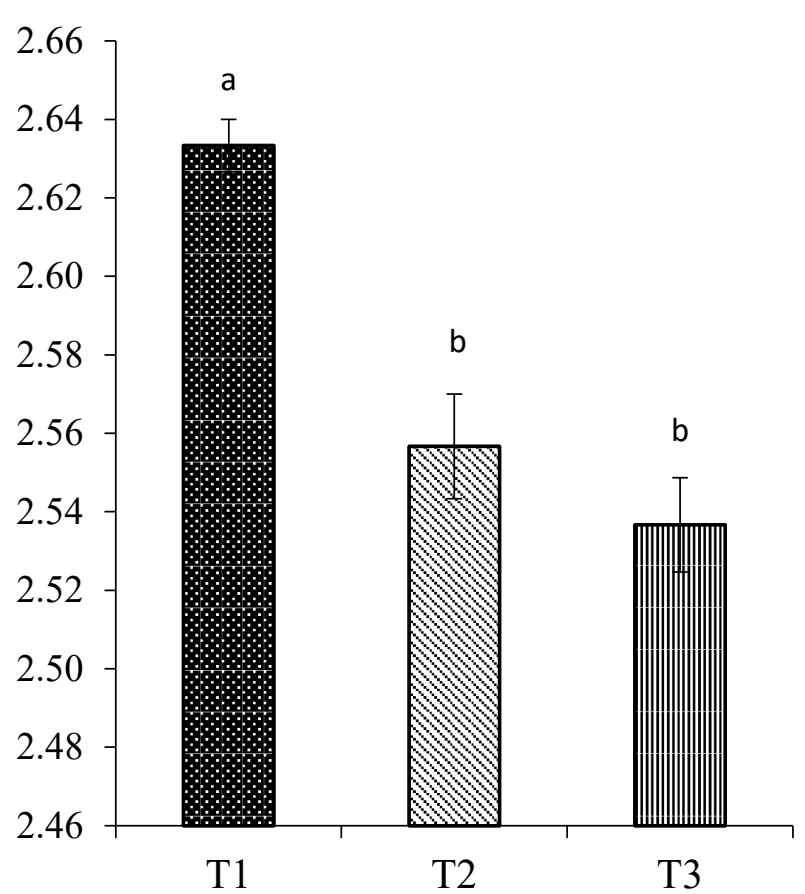

Figure 2. Effect of different fertilization strategies on bulk density and particle density after wheat harvest (three replicates)

Whereas, $T_{1}=$ Urea; Recommended $N$ from Urea, $T_{2}=$ Urea $(80 \mathrm{~kg})+$ FYM $(10$ ton $)$ and $T_{3}=$ FYM $(20$ ton $)$

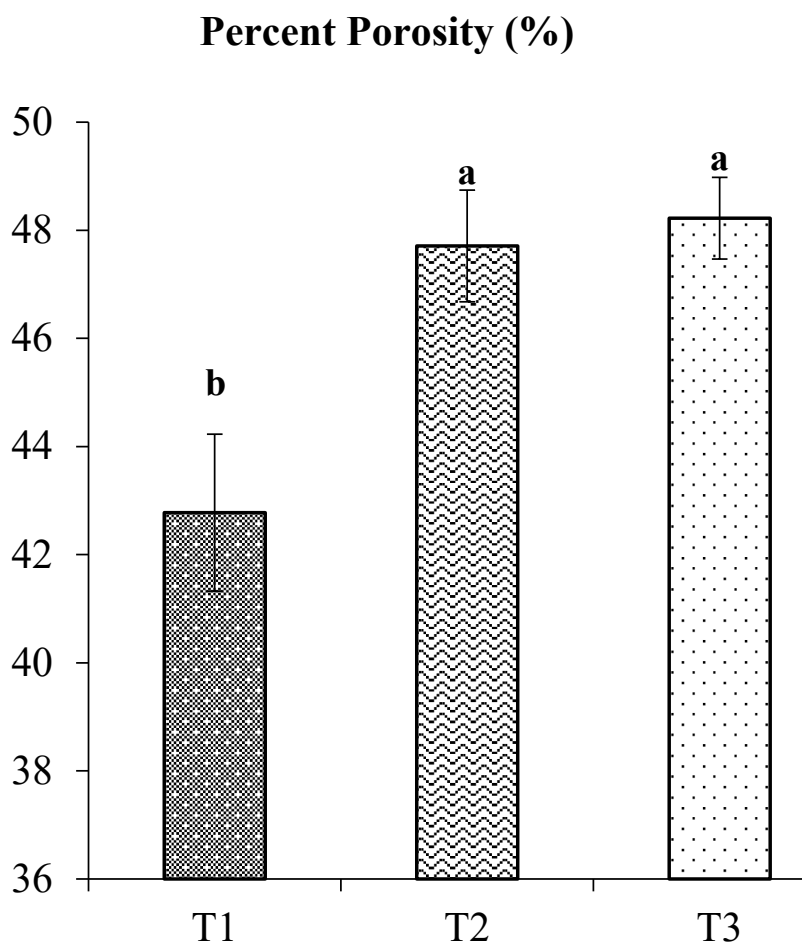

\section{Saturated Hydraulic Conductivity $\left(\mathrm{mm} \mathrm{hr}^{-1}\right)$}

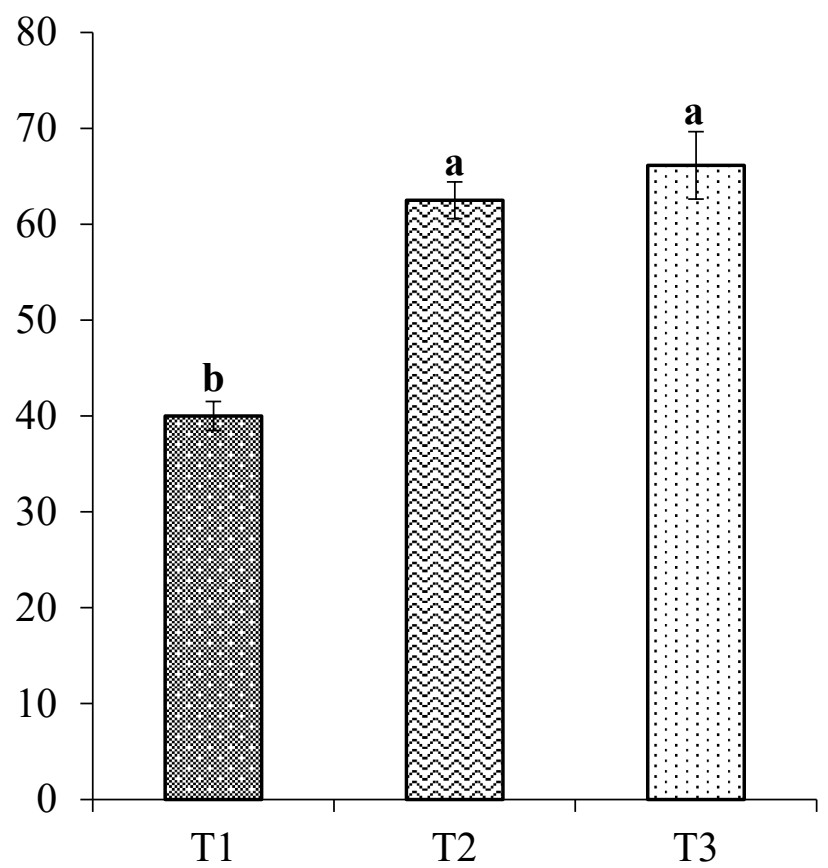

Figure 3. Effect of different fertilization strategies on soil percent porosity and saturated hydraulic conductivity after wheat harvest (three replicates)

Whereas, $T_{1}=$ Urea; Recommended $N$ from Urea, $T_{2}=$ Urea $(80 \mathrm{~kg})+$ FYM $(10$ ton $)$ and $T_{3}=$ FYM $(20$ ton $)$ 


\section{References}

[1] USDA, GAIN Report Number PK1704. USDA Foreign Agricultural Service (2018).

[2] FAO, Food and Agriculture Organization of United Nations (2013).

[3] H.S. Atkinson, D.L. Sparkes, S.J. Mooney, Using selected soil physical properties of seedbeds to predict crop establishment, Soil and Tillage Res. 97 (2007) 218-228.

[4] S.J. Leghari, N.A. Wahocho, G.M. Leghari, A.H. Leghari, G.M. Bhabhan, K.H. Talpur, T.A. Ghutto, S.A. Wahocho, A.A. Lashari, Role of Nitrogen for plant growth and development: A Review, Advances in Environmental Biology. 10 (2016) 209-218.

[5] M.S. Bianco, A.B. CecílioFilho, L.B. Carvalho, Nutritional status of the cauliflower cultivar Verona grown with omission of out added macronutrients. Plos One. 10 (2015) 1-17.

[6] S.A. Uhart, F.H. Andrade, Nitrogen deficiency in maize effect on crop growth, development to dry matter partitioning, and kernel set, Crop Sci. 35 (1995) 1376-1383.

[7] K.C. Cameron, H.J. Di, J.L. Moir, Nitrogen losses from the soil/plant system: a review, Ann Appl Biol. 162 (2012) 145-173.

[8] P.S. Hooda, A.C. Edwards, H.A. Anderson, A. Miller, A review of water quality concerns in livestock farming areas, The Sci Total Environ. 250 (2000) 143-167.

[9] H.J. Di, K.C. Cameron, Nitrate leaching in temperate agroecosystems: sources, factors and Mitigating strategies, Nut Cycling Agroecosystems. 46 (2002) 237-256.

[10] K. Khurshid, M. Iqbal, M.S. Arif, A. Nawaz, Effect of tillage and mulch on soil physical properties and growth of maize, Int J Agric Biol. 5 (2006) 593-596.

[11] FAO, Fertilization and Plant Nutrition Guide. Food and agricultural organization of the United Nations, Rome, Italy (2010).

[12] A. Franzluebbers, F. Magdoff, R. Ray, Tillage and residue management effects on soil organic matter, in: Soil organic matter in sustainable agriculture. CRC Press Inc. pp. (2004) 227-268.

[13] B. Sing, A.P. Sing, Response of Wheat (Triticum aestivum L.) to FYM and Phosphorus Application in Alluvial Soil, Int J Curr Microbiol App Sci. 7 (2018) 418-423.

[14] Zahoor, W. Ahmad, K, Hira, A. Khan, M.T. Jan, K. Akhter, Bashir-ullah, Integrated use of farm yard manure and urea fertilizer enhanced tissue nitrogen of wheat at different growth stages. Journal of Biology, Agriculture and Healthcare. 5 (2015) 98-105.

[15] S.A. Mazhar, M. Nawaz, S. Khan, S. Irshad, Impact of urea and farm yard manure on nitrate concentration in soil profile and productivity of wheat crop, Journal of Plant Nutrition. 41 (2018) 2683-2691.

[16] G.R. Blake, K.H. Hartge, Bulk density. In: A. klute (ed.) Methods of soil analysis part 1. Physical and Mineralogical Methods. Agronomy Monograph No.9, 2nd Ed., P. (1986) 363-375. Madison, WI, USA.

[17] R.G.D. Steel, J.H. Torrie, D.A. Dickey, Principles and Procedures of Statistics: A Biometric Approach. McGraw Hill Book Co. In., New York, USA (1997).

[18] S.A. Shah, S.M. Shah, W. Muhammad, M. Shafi, H. Nawaz, S. Shehzadi, M. Amir, Effect of integrated use of organic and inorganic nitrogen sources on wheat yield, Sarhad J Agric. 26 (2010), 559-563.

[19] R. Singh, S.K. Agarwal, Growth and yield of wheat (Triticum aestivum L.) as influenced by levels of farmyard manure and nitrogen, Indian J Agron. 46 (2001) 462-467.

[20] A.S. Iqbal, M.K. Abbasi, G. Rasool, Integrated plant nutrition system (IPNS) in wheat under rainfed condition of Rawalkot Azad Jammu and Kashmir, Pa. k J Soil Sci. 21 (2002) 79-86. 
[21] M. Arif, S. Ali, A. Khan, T. Jan, M. Akbar, Influence of farm yard manure application on various wheat cultivars, Sarhad J. Agric. 22 (2006) 27-29.

[22] H. Shirani, M.A. Hajabbasi, M. Afyuni, A. Hemmat, Effects of farmyard manure and tillage systems on soil physical properties and corn yield in central Iran, Soil Till. Research. 68 (2002) 101108.

[23] M.J. Kiani, M.K. Abbasi, N Rahim, Use of organic manure with mineral N fertilizer increases wheat yield at Rawalakot Azad Jammu and Kashmir, Arch Agro Soil Sci. 51 (2005) 299-309.

[24] A. Khan, M.T. Jan, K.B. Marwat, M. Arif, Organic and inorganic nitrogen treatments effects on plant and yield attributes of maize in different tillage systems. Pak J B. 41 (2009) 99-108.

[25] S.N. Maobe, L.S.M. Akundabweni,M.W.K. Mburu, J.K. Ndufa, J.G. Mureithi, C.K.K. Gachene, F.W. Makini, J.J. Okello, Effect of mucuna green manure and inorganic fertilizer urea nitrogen sources and application rates on harvest index of maize (Zea mays L.), World Journal of Agricultural Sciences. 6 (2010) 532-539.

[26] T.G. Sommerfeldt, C. Chang, Changes in soil properties under annual applications of feedlot manure and different tillage practices. Soil Sci Soc Am J. 49 (1985) 983-986.

[27] M.R. Mosadeghi, A.A. Mahboubi, A. Safadoust, Short-term effects of tillage and manure on some soil physical properties and maize root growth in a sandy loam soil in Western Iran, Soil and Tillage Research. 104 (2009) 173-179.

[28] R.J. Haynes, R. Naidu, Influence of lime, fertilizer and manure applications on soil organic matter content and soil physical conditions: a review, Nutrient Cycling in Agroecosystems. 51 (1998) 123-137.

[29] D.C. Edmeades, The long-term effects of manures and fertilizers on soil productivity and quality, Nutr Cycl Agroecosystem. 66 (2003) 165-180.

[30] J.J. Miller, N.J. Sweetland, C. Chang, Hydrological properties of a clay loam soil after long-term cattle manure application, J Envt Quality. 31 (2002)989-996.

[31] M.A. Iqbal, A.U. Hassan, A. Ali, M. Rizwanullah, Residual effect of tillage and farm manure on some physical properties and growth of wheat (Triticum aestivum L.), Int J Agri Biol. 7 (2005) 5457.

[32] D. Gozdowski, E. Leszczynska, M. Stępien, J. Rozbicki, S. Samborski, Within-field variability of winter wheat yield and grain quality versus soil properties, Communications in Soil Science and Plant Analysis. 48 (2017) 1029-1041. 